\title{
Measuring Excellence: A Closer Look at Malcolm Baldrige National Quality Award Winners in the Manufacturing Category
}

Brian Cazzell, Jeffrey M. Ulmer*

\begin{abstract}
TThe Malcolm Baldrige National Quality Award is the nation's highest quality award. The application and review process is outlined in this work. The objective of this study was to examine the five previous winners in the Manufacturing category and to establish a firm conclusion about the award's impact. The impact of the award was examined in several categories including financial performance, market share, and employee productivity. This study explored the accomplishments of each company and compared the common factors they shared with one another. It was found that all five companies experienced tremendous financial growth on average of $100 \%$ in either sales or revenue as a result of their dedication to quality which ultimately led to winning the MBNQA.
\end{abstract}

Keywords: Malcolm Baldrige National Quality Award, MBNQA, manufacturing, award impact.

* School of Technology, University of Central Missouri 


\section{Introduction}

Organizational excellence can be measured in many different ways. There are countless awards given every year to companies who are striving for excellence in some shape or form. Some companies seek notoriety for the sake of being able to claim their supremacy in their respective industry, while other companies just want the title of "award winning" in front of their product or service. With so much emphasis placed on buying only the best products and services, consumers are faced with the challenge of wading through the muddy waters of what each award represents and trying to make the ultimate decision of which company is worth their patronage. To make matters worse, consumers are hit with a barrage of television commercials from many different manufacturers who claim to have received a Consumer's Digest Best Buy Award (C) or a J. D. Power and Associates customer satisfaction and quality award (C). While all of these different awards and titles are intended to identify which company or product is superior, only one program has the President of the United States seal of approval: the Malcolm Baldrige National Quality Award (MBNQA).

The Malcolm Baldrige National Quality Award was established 20 years ago in 1987 by the U.S. Congress in an effort to promote quality improvement initiatives in U.S. businesses. The award program was named after former Secretary of Commerce, Malcolm Baldrige, and was designed and managed by the National Institute of Standards and Technology (NIST) with the help of private companies. Other organizations play a vital role in the successful management and longevity of the program. A foundation was created with purpose of raising funds to "permanently endow the award program" (NIST Criteria, 2008). The foundation's trustees are prominent leaders in various U.S. companies and are charged with ensuring the organizations objectives are accomplished. Another vital partner of the award program is the American Society for Quality (ASQ). ASQ operates under a contract to assist in the administration of the program in conjunction with NIST and other governing bodies (NIST Criteria, 2008). ASQ's reputation of being the "leading membership organization devoted to quality" is known throughout the world (ASQ, 2008) and greatly contributes to the program's validity and stature. A Board of Overseers also assists and directly advises the Department of Commerce in matters pertaining to the program. Board members are appointed by the Secretary of Commerce and consist of "distinguished leaders from all sectors of the U.S. economy" (NIST Criteria, 2008).

According to NIST, the criteria are focused on two goals: "delivering ever improving value to customers and improving the organization's overall performance" (NIST, 200I). The award is regarded as the highest honor a company can receive in the field of quality and performance excellence (NIST, 200I), and is awarded annually. There are six categories of award recipients; manufacturing, small business, service, education, and health care and the award was also expanded in 2007 to include nonprofit organizations. But what impact has this award had on its recipients and what does it take to win the most prestigious quality award in the country? In order to determine these factors, we will look closely at the five previous winners in the manufacturing category. Those companies include: Sunny Fresh Foods, Inc in 2005; the Bama Companies in 2004; Medrad, Inc. in 2003; Motorola Inc. Commercial, Government and Industrial Solutions Sector 2002; and Clarke American Checks, Incorporated in 2001 .

\section{Application and Review Process}

In order to examine its impact we must first understand the stringent application process that is involved. In 2008, the application fee for companies competing in the manufacturing category was $\$ 6,000$ and another $\$ 2,000$ supplemental fee was required for companies who have more than one performance system to evaluate. As far as the content of the application is concerned, companies must "submit details showing their achievements and improvements in seven key areas: leadership; strategic planning; customer and market focus; measurement, analysis, and knowledge management; human resource focus; process management; and results" according to the NIST website (NIST, 200I).

According to the 2008 "Criteria for Performance Excellence" guide published by NIST, a board of examiners is selected through a competitive application process and the examiners that are chosen represent a wide variety of experts in each respective award category. For the 2008 award cycle, a total of approximately 570 board members were chosen. Out of the 570 members, 12 members are personally appointed by the Secretary of Commerce, and approximately 100 of the 570 members are chosen as senior examiners (NIST Criteria, 2008). The board of examiners will spend anywhere between 300 to I,000 hours reviewing the company's individual attributes and identifying areas for potential improvement (NIST, 200I). The application review is performed in three stages; stage one is the independent review, stage two is the consensus review, and stage three is the site visit review.

During the first stage, or the independent review stage, each application is evaluated by members of the board of examiners which have been chosen based on their area of expertise. Each examiner writes comments from their findings from the initial application and scores the applicants using a scoring system developed for the award program. At the conclusion of stage one, a panel of judges determines which applicants move on to the second stage, or the consensus review stage. For those appli- 
cants not chosen to move on to the second stage, a detailed report is then prepared to provide feedback on their strengths and weaknesses and areas for improvement. This is where the program appears to offer the greatest return on investment to companies who apply. After all, many companies are willing to pay expensive consultant fees to perform the same type of audit just for the sake of continuous improvement efforts not associated with the award.

During the second stage, or the consensus review stage, a senior examiner is responsible for compiling all of the information presented by a team of examiners and ensures that the group reaches a consensus on their overall view of the applicant's strengths and weaknesses. Also, the team decides the applicants' overall score and any other issues that need to be addressed during a site visit if one is to be performed. Similar to stage one, if candidates in the second stage are not chosen for the third stage, the detailed feedback report is then finalized and forwarded to the applicants.

If the board of examiners decides an applicant is deserving of a closer look, a site visit is conducted as the third stage and final stage to verify the information on the application, review records, conduct any necessary interviews, and to clarify any other data or information from the review process that is unclear to the examiners. The examination teams consist of six to eight examiners and are responsible for making final award recommendations to the Secretary of Commerce (NIST, 2007). According to the 2008 application guideline, companies that earn a site visit from the evaluation team should be prepared to spend anywhere from $\$ 20,000$ to $\$ 35,000$ for larger companies with over 500 employees but could be as much as half of that estimate for smaller businesses. Once the site visits are completed, the material including applications, scorebooks, and site visit reports are handed over to the panel of judges for a final multi-voting and nominal group technique ranking process to determine the winners. The panel of judges may select up to three winners in each category that meet the overall criteria.

\section{Award Impact to Five Manufacturing Companies}

The overall impact of the award program is easy to see. NIST claims there have been I 49 applications submitted from a wide variety of businesses since 1988 (NIST, 200 I). In addition, there are now over 40 programs which are mostly modeled after the Baldrige program running in $4 \mathrm{I}$ states which is an increase of over $300 \%$ in the short lifespan of the program. The award program has made an international impact as well with over 80 programs abroad. With results such as this, one could argue that quality is one of the biggest commodities for any business trying to compete in today's global marketplace. Despite this, the numbers of applications received in the manufacturing cat- egory have slowly dwindled over the years. In 1988, 45 applications were received, 10 site visits were conducted, and two awards were given. When compared to the figures from 2007, only two applications were received, no site visits were conducted, and no awards were given which either indicates a general lack of interest in the award program or a lack of qualified applicants. With fewer companies applying over recent years, the chances for winning the award are greatly improved. However, there are no guarantees that the award will be given as evidenced in 2006 and 2007 when there were no winners in the manufacturing category despite receiving a total of five applications for both years.

Financially speaking, the program has many benefits to the aggregate economy. According to ASQ, "Economists measured the impact of the Baldrige Award on the economy. They determined that the social rate of return is 207 to I.That is, for every dollar invested in the program the economy receives a benefit of \$207" (ASQ News, n.d.). Additionally, award recipients receive the notoriety of winning the world class award and the recognition of becoming the new benchmark that other companies must look up to in the areas of quality improvement and management practices. Winners of the award are also expected to share their knowledge and best practices as a way of educating and furthering the case for quality.

Since establishing the need for higher quality standards in manufacturing is considered easy, a company that is contemplating applying for this award might want to see other incentives besides the notoriety that comes from winning the award. Businesses may also want to consider other areas such as the direct impact of the award on sales and revenue. If there is no value added for shareholders in any quality improvement initiative, the decision to go forward with the application process of the Baldrige award will be a tough one to make.

The previous five winners of the MBNQA have taken a very similar path down a sometimes windy and tumultuous road towards achieving quality excellence, but the results were well worth the risks. Sunny Fresh Foods, The Bama Company, Medrad, Motorola, and Clarke American have many things in common that has greatly contributed to earning the title as a winner of the MBNQA. By examining their similarities, successes, and ideologies, one could easily create a blueprint for their own organization's success or at the very least a snapshot of the results that are achievable due to developing and implementing a quality program. Figure I highlights outcomes for these five manufacturing category Baldrige award winners. Since no winners were selected in the manufacturing category in 2006 and 2007 we will begin with the 2005 winner, Sunny Fresh Foods. 


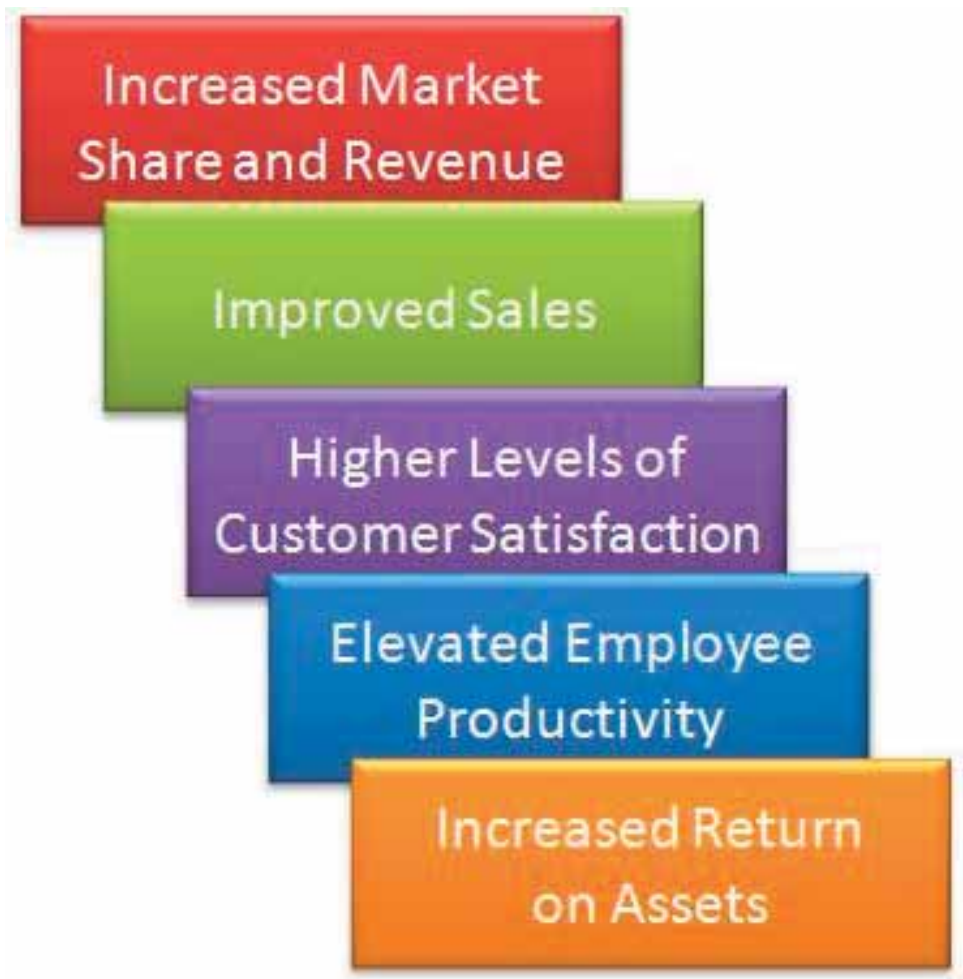

Figure I. Outcomes for five manufacturing Baldrige award winners

Sunny Fresh Foods

The most recent winner in the manufacturing category is Sunny Fresh Foods (SFF), who won the award the 2005. They also have the distinction of becoming the first food manufacturing company to receive the award twice by previously winning the award in 1999 as well as 2005. Sunny Fresh Foods (now a brand name of Cargill Kitchen Solutions) is a global supplier of egg based products such as diced eggs, liquid eggs, and other egg entrees to other food service industries which includes restaurants, and educational and military institutions (Cargill Inc., 2007). According to NIST, revenues have increased a staggering 93 percent since receiving the award the first time in 1999 , and "from 200 I to 2005, sales per employee and profit per employee have increased by 19 percent" (NIST, 2007). Upon closer examination of Cargill's financial statement, the company has experienced sustained growth in sales and revenue between 2005 and 2007 by an increase of 24 percent since receiving the award for the second time in 2005 (Cargill Inc., Financial Highlights, 2007). Another noteworthy trend is the increase of the market share of Sunny Fresh Foods. Over the past four years, Sunny Fresh has managed to increase its market share while their competitor's market share has decreased by $10 \%$. In today's ever-changing global market place, obtaining market share early is critical in the success of any company. By demonstrating their ability to not only maintain market share but also increase it, Sunny Fresh Foods is ensuring profitability for shareholders for many years to come. Just examining the financial results or impact the award has made on SFF, it would be easy to determine just how important this award has clearly become to those who seek after it.

Aside from financial benefits, Sunny Fresh Foods has experienced many other noteworthy results as well. For instance, as a byproduct of many continuous quality improvement initiatives, Sunny Fresh Foods has never had a food safety related product recall since being acquired by Cargill in 1985 (NIST, 2007). Lately the topic of product recalls has flooded our news media and press stories. The U.S. has recently experienced massive recalls in pet food, tooth paste, children's toys, automobile tires, and the list goes on forever with ill-manufactured products. In the month of April 2008 alone, there are over 20 product recalls according to the U.S. Consumer Product Safety Commission's website (www.cpsc.gov). It is results such as this that gives Sunny Fresh Foods the right to be proud of their track record especially since the impact of these recalls can cost a company several million dollars and completely damage their reputation. By accomplishing this monumental feat, Sunny Fresh Foods has clearly established their reputation as a global leader in quality initiatives that other companies should aspire to emulate. In order to achieve this benchmark, SFF provides monthly training to employees on topics such as food safety, 
personal safety, and best practices. Since one of the key factors for motivating employees is to provide them with a solid training program, SFF is not only equipping their employees with the knowledge and training to make the right choices at work, but to carry out their duties with dedication and compassion for their company. This would clearly have an impact on the level of quality SFF is able to achieve.

\section{The Bama Company, Inc.}

Another food manufacturing company to win the award is the Bama Company, Inc., which was the recipient of the award in 2004 from among only 60 candidates in all five categories (NIST, 2004). Bama has remained a family owned and operated business in Oklahoma since 1927. They manufacture quick-serve frozen food products used in fast food and casual dining restaurants including McDonald's and Pizza Huts located throughout the world (NIST Bama, 2007). They manufacture their products in only four facilities in Oklahoma and two in Beijing, China but produced $\$ 200$ million in revenues.

In addition to winning the Malcolm Baldrige award, Bama has also recently earned the U.S. Quality Supplier Award by McDonald's in 2005 (Bama, 2006). The award is presented to "the nation-wide food, paper or product supplier that demonstrates outstanding commitment and achievement in ongoing quality improvement through technology, formal quality improvement activities and innovation in approach to quality" (Bama, 2006). Among the various quality related awards this company has received over its 80 year history is the centerpiece of what makes their success possible; a philosophy of consistent quality. Paula Marshall, CEO, stated, “...one timeless principle endures from then until now: consistent quality. No matter how much we grow and evolve, that's one part of the Bama story that will never change." (Bama, n.d.)

Financially speaking, Bama has grown exponentially from 1999 to 2004 with an increase in sales of over $72 \%$ and revenue increases of almost $100 \%$ in the same time period (Malcolm, 2004). With such a huge growth in revenue it would be easy to think that the company is simply raising prices in order to generate revenue, but after reviewing Bama's Baldrige award application summary, one glaring fact that many companies would be proud to boast, if they could, is; Bama has not raised prices on their two biggest selling products, biscuits and small pies, since 1996. Another striking fact mentioned on their application is in order to offset the rising costs of raw ingredients; the company has begun to adopt many Six Sigma production methodologies. The result of adopting Six Sigma methodologies has been determined to be a cost avoidance of $\$ 17$ million dollars since 200 I (Malcolm, 2004). Their journey took I 3 years to complete, and despite not winning the award for several attempts they used the feedback received each year as a quality improvement tool. This journey included bringing in a Six Sigma Blackbelt, Mike Frihart, who solely dedicated himself each year from February to May to painstakingly complete the application for the upcoming year's competition (Seiz, 2005). By establishing themselves as an organization that is willing to continuously improve itself, they not only trimmed costs in many areas but have also been able to lower prices to their major customers which is a business practice that is quickly becoming the standard in order just to survive in today's global economy.

The Bama Company has also thought of other ways to motivate their employees to perform at peak standards and produce high quality products. The company rewards its employees with a financial incentive based on the company's success. Since 2001 each employee has received a bonus of approximately $\$ 3,000$ annually (Malcolm, 2004). By offering such generous financial incentives, they are more likely to retain the most highly skilled workers which produce the best possible product. Another benefit of offering bonuses based on the company's success is they are able to build loyalty and a sense of caring for their employees. Over time this loyalty would positively impact the level of corporate knowledge possessed by each employee, thus making the workforce more valuable to the company. The by-product of this would be less money spent on training new workers due to a lack of employee turnover. This can be viewed as a critical element in maintaining proper quality levels that the company so desires to uphold.

\section{Medrad, Inc.}

The recipient of the MBNQA in 2003 is Medrad, Inc., a medical device manufacturing company headquartered in Pittsburgh, Pennsylvania. The company was founded in 1964 by Dr. M. Stephen Heilman who created "the first flow-controlled, angiographic power injector" in the kitchen of his own home (Medrad, 2007). Since their humble beginnings, Medrad has grown into a worldwide manufacturer of medical imagining devices which are sold and distributed to 85 countries. They currently employ more than I,700 people in 18 locations around the globe (Medrad, 2007). To illustrate the growth Medrad has experienced since winning the award in 2003, their sales have seen an increase of almost 100\% from $\$ 254$ million to $\$ 478$ million in the last four years and their company has added approximately $50 \%$ more staff from nearly I,200 to I,700 during the same time period. Additionally, Medrad spent nearly onehalf million dollars in $\mathbf{2 0 0 2}$ for the reimbursement of educational expenses for employees which shows they are truly committed to the professional development of their staff (Malcolm, 2003). 
Since the introduction of the MBNQA in 1988, Medrad has been on what they call the "Baldrige Journey" (Medrad, 2007). The Baldrige Journey highlights the major quality improvement initiatives taken by the company over the last 19 years on their road to winning the coveted award. Beginning in 1988, they initiated their own form of total quality management program called Quality For Life ${ }^{\circledR}$ which "focused primarily on product and service quality, on-time delivery and customer satisfaction" (Medrad, 2007). In 1990, Medrad created its first quality policy which still exists today and confirms their overall dedication to their customers. In 1994, Medrad used the Malcolm Baldrige criteria to assess their own quality program against the award's standard. Nearly eight years after they began taking initiatives to prepare themselves for the award application process, Medrad submitted their first official application to the award program in 1996. The company applied again in the following three years, and although they did not win the award, they were one of only a handful of finalists to receive a site visit by the examiners. Finally, after their fifth attempt at applying for the award, all of their efforts and initiatives paid off as they became the winner of the award in 2003.

Motorola Inc.

The award recipient in 2002 was Motorola's Commercial, Government, and Industrial Solutions Sector (CGISS). The CGISS manufactures two-way radios and related communication network products which are used by customers such as fire and police departments, government organizations including homeland security and military services, and other industrial businesses where two-way radio communication is vital. CGISS is headquartered in Schaumburg, Illinois but has a global presence in nearly every other continent. CGISS operations require the support of over 14,000 dedicated employees who also "enable customers to achieve their mission and improve their operational performance with integrated information and communication solutions" (NIST Motorola, 2002).

Motorola is known throughout the world as a global leader in quality initiatives and is credited with establishing the Six-Sigma methodologies. The Six Sigma methodologies have since been adopted by nearly every large manufacturing facility in the world so it comes as no surprise that a quality-conscious company such as Motorola would have won the award for a second time. The company's history of using process improvement and quality improvement initiatives dates back to 1986. Since then, Motorola has been using six-sigma to identify areas for improvement, reduce errors, and improve performance in many of their functional areas including manufacturing which they claim was instrumental in winning the first ever MBNQA in 1988 (Motorola Inc., 2007).
For their most recent award, many success factors were considered within the CGISS. For example, from 1999-2002 employee productivity increased by over $30 \%$, and overall customer satisfaction levels were nearly $90 \%$. Financially speaking, CGISS was not only stable during very lean years of the U.S. economy; it had a "7 percent return on assets versus a negative average for the telecommunications industry" (NIST Motorola, 2002). Additionally during the same period, CGISS experienced an improved cash flow as a percent of revenue of $20 \%$ compared to an industry average of only $5 \%$ (Motorola, 2004). Not only is Motorola a leading innovator in quality related issues, they are also in tune with their social responsibility to the environment. Since 1996, CGISS recycled nearly $60 \%$ of their non-hazardous waste and reduced their plant emissions by nearly $90 \%$ (NIST Motorola, 2002).

After analyzing selected financial data for the entire company, it is clear to see the residual effect of not only winning the MBNQA twice in two decades but also creating and implementing Six-Sigma methodologies in all sectors of the business. Even though CGISS represents only about $20 \%$ of the overall income of Motorola, Inc their performance across the board has been phenomenal. After winning the award in 2002, financial performance for Motorola Inc. has steadily increased from \$22 billion in 2002 to over $\$ 42$ billion in 2006 in net sales which is nearly a $100 \%$ increase. Motorola Inc. has also improved from an overall net loss of $\$ 2.5$ billion in 2002 to a net earning of $\$ 3.6$ billion in 2006 (Motorola, 2006).

\section{Clarke American Checks, Inc.}

The winner of the 200I MBNQA is Clarke American Checks, Inc. which provides check printing services, financial forms, and other banking related documents to over 4,000 financial institutions in the U.S. The company is headquartered in San Antonio, Texas and has been in business for nearly 135 years. Clarke has withstood the test of time and has witnessed many technological advances in the financial world but has continually found a way to adapt their products and services to meet current demands. Currently they employ over 3,000 personnel and operate nine manufacturing facilities. They also operate four call centers which enable(s) them to conduct business 24 hours a day, 7 days a week (Clarke, 2007).

In order to remain competitive in the $\$ 1.8$ billion industry, Clarke created what they call "First In Service®" (FIS) approach to providing outstanding service and business excellence. For Clarke employees, the FIS provides an outline for providing excellent customer service and superior performance. According to NIST, "FIS is the foundation and driving force behind the company's continuous improvement initiatives; it aligns Clarke 
American's goals and actions with the goals of its partners and the customers of these financial institutions" (NIST Clarke, 2002). Clarke American clearly believes in Total Quality Management (TQM) philosophy which has bred a culture of open communication and creativity from their employees. As a result, Clarke American was able realize an estimated cost savings of $\$ 10$ million in 2001 by implementing 20,000 process improvement ideas that came from their employees (NIST Clarke, 2002). As a result of these improvements, employees averaged $\$ 5,000$ in profit sharing bonuses and rewards. In the previous year, employees received an average of 76 hours of training which far exceeds the industry average, which clearly shows Clarke's commitment to the personal and professional development of their employees.

Clarke's financial results have also reflected the company's commitment to their employees and customers. Since 1996, Clarke American's market share has increased by $50 \%$; however, they only maintain approximately $5 \%$ of the overall market share against three major competitors. Despite fierce competition and major industry consolidations, Clarke American's revenues were over $\$ 460$ million in 200 I (NIST Clarke, 2002) which equates to each employee generating over $\$ 139,000$ of revenue each. Additionally,"annual growth in company revenues has increased from a rate of $4.2 \%$ in 1996 to $16 \%$ in 2000 , compared to the industry's average annual growth rate of less than one percent over the five-year period" (NIST Clarke, 2002).

\section{Summary and Conclusions}

After closely examining the five previous winners of the MBNQA in the manufacturing category, it is easy to see many common denominators that contributed to not only the successful operation of each company but the sustainable growth each company has achieved. Each of the five companies experienced remarkable financial growth in the few years leading up to the subsequent award and also in the many years afterwards as well. Clearly, these five companies have provided a roadmap or a blueprint for other companies to follow. Even though the road may appear long and arduous to the new onlooker, there are other ways to take advantage of the Baldrige program without diving in head first. Initially, companies should begin by performing a self-evaluation utilizing the "Baldrige Criteria for Performance Excellence" which provides benchmarking guidelines in "validated, leading-edge management practices" (NIST Criteria, 2008). Not only can this tool be used to prepare an organization for the award process but it can also help make discoveries in areas that need improvement regardless of the application status.
Winning the award does not guarantee an organization's financial success. There are other factors that play a vital role such as the effectiveness of the company's strategic plan and business model. Assuming these areas are being properly managed it is not uncommon to link winning the MBNQA to financial success as proven in these five examples. Clearly the financial performance is the number one concern for shareholders. Therefore, in order to prove the value of the award the Baldrige program created a stock study that spanned from 1995 through 2004. The stock study measured the success of the award winners against the S\&P 500. The study gave investors a better understanding of the financial impact the award has on its recipients and aids in solidifying the importance of quality improvement initiatives. The study measured only those award winning companies which were publicly traded and the results from the majority of those years spoke loud and clear about the significance of winning the award. Until 2000, those publicly traded companies in the "Baldrige Index consistently outperformed the S\&P 500 by as much as 6.5 to I" (NIST Tech Beat, 2004). The numbers produced in the stock study are also supported by the results found in these five examples where the average increase in either sales or revenue reached or exceeded $100 \%$ in a relatively short time-frame surrounding the date of each respective award.

Aside from improved financial performance, the five winners also shared similar positive results in the areas of customer satisfaction rates, employee productivity, and increased market shares. When all of these elements are combined, a winning formula is uncovered for those who seek the same level of success. After studying these winners, it is easy to understand why the award is highly coveted and why I I 00 applicants have previously vied for a chance to win the MBNQA, and why countless organizations have measured themselves against the award criteria and the benchmarks set by its recipients (see Figure 2 for other tasks of significance).

The dramatic results seen in these examples were due in large part to the high level of commitment to quality that was demonstrated by each organization's top level managers. No one else but the late Joseph Juran, known as the "Father" of Quality, could have more eloquently spoken such an appropriate summary of what is needed for successful implementation of quality programs by stating, "It is most important that top management be quality-minded. In the absence of sincere manifestation of interest at the top, little will happen below" (ASQ, 2008). 


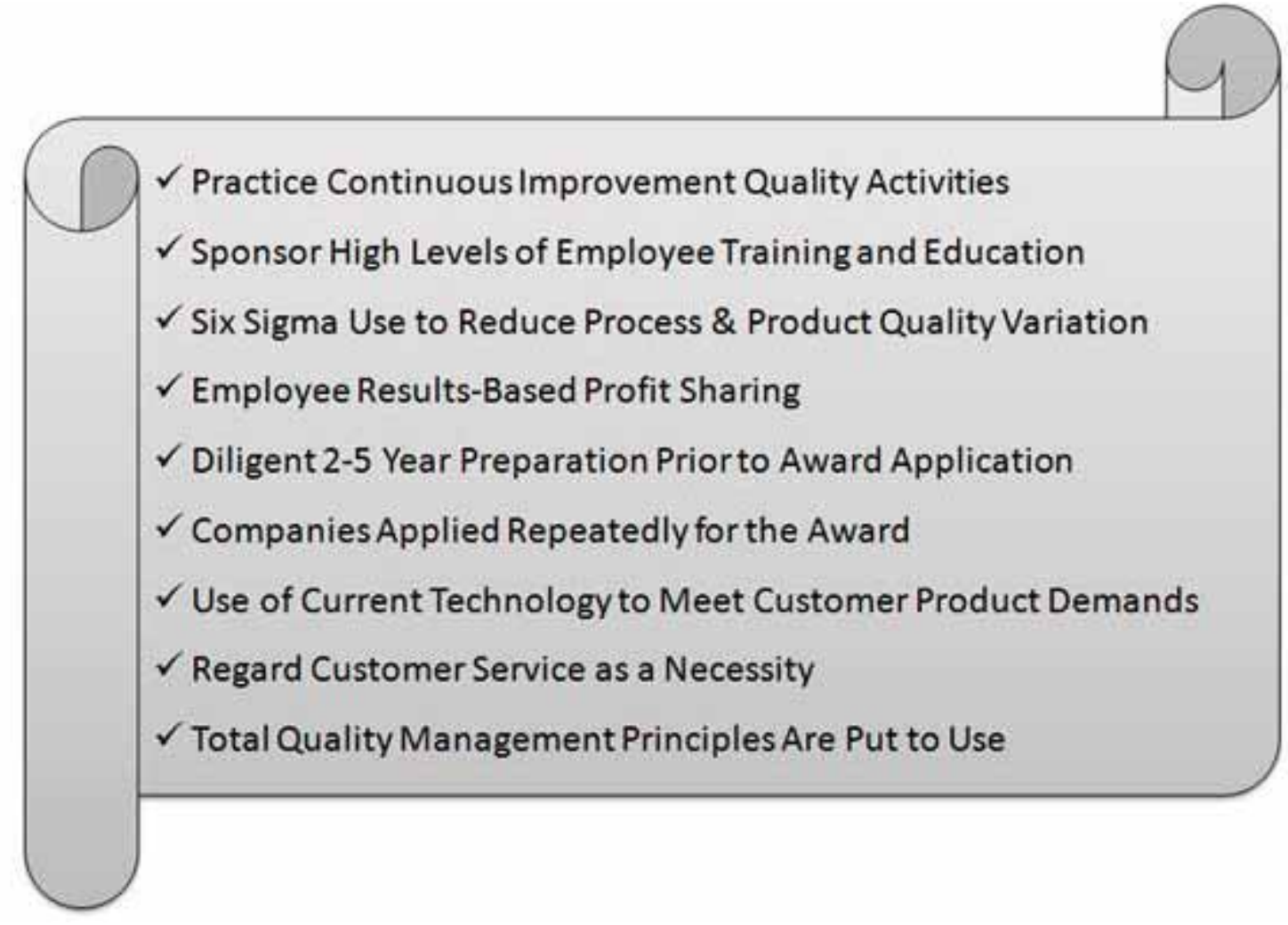

Figure 2. Baldrige award winner tasks of significance

\section{References}

American Society for Quality, ASQ News (n.d.). The Baldrige award at age twenty. Retrieved March 28, 2008, from http://www.asq.org/media-room/news/2007/02/200702 I5baldrige-age20.html

American Society for Quality (2008). Retrieved April 21, 2008, from http://www.asq.org/

CARGILL Inc. (2007). Financial highlights. Retrieved November 26, 2007, from http://www.cargill.com/about/financial/financialhighlights.htm\#TopOfPage

CARGILL Inc. (2007). Sunny Fresh Foods. Retrieved November 26, 2007, from http://www.sunnyfreshfoods.com/

Clarke American Checks, Inc. (2007). About Clarke American. Retrieved December 8, 2007, from https://www.clarkeamerican.com/about/coprofile.jsp

Malcolm Baldrige National Quality Award (2003). 2003 Award winner: Medrad, Inc. Retrieved December 2, 2007, from http://www.nist.gov/public_affairs/baldrige2003/Medrad_3.3.04. pdf
Malcolm Baldrige National Quality Award (2004). 2004 Award winner:The Bama Companies, Inc.” Retrieved November 28, 2007, from http://www.nist.gov/public_affairs/BamaPDFfinal.pdf

Medrad, Inc. (2007). About Medrad. Retrieved December 2, 2007, from http://www.medrad.com/about-medrad/history.html

Motorola, Inc. (2004). CGISS best practices. Retrieved December 8, 2007, from http://www.motorola.com/governmentandenterprise/contentdir/en_US/Files/ProductInformation /MalcolmBaldrigePerformanceExcellenceBestPractices.pdf

Motorola, Inc. (2006). 2006 Annual report. Retrieved December 8, 2007, from http://library.corporate-ir.net/library/90/908/90829/items/233764/2006\%20Motorola\%20Annu al\%20Report\%20on\%20Form\%20I0K.pdf

Motorola, Inc. (2007). About Motorola University:The inventors of Six Sigma. Retrieved December 8, 2007, from http://www.motorola.com/content.jsp?globalObjectld=3079

National Institute of Standards and Technology (NIST) (200I). Malcolm Baldrige National Quality Award. Retrieved November 25, 2007, from http://www.nist.gov/public_affairs/ factsheet/mbnqa.htm 
National Institute of Standards and Technology (NIST) (2002). Malcolm Baldrige National Quality Award 200I award recipient, manufacturing category: Clark American Checks, Inc.. Retrieved December 8, 2007, from http://www.nist.gov/public_affairs/clarke.htm

National Institute of Standards and Technology (NIST) (2002). Malcolm Baldrige National Quality Award 2002 award recipient, manufacturing category: Motorola Inc. commercial, government and industrial solutions sector (CGISS). Retrieved December 5, 2007, from http://www.nist.gov/public_affairs/releases/ cgiss.htm

National Institute of Standards and Technology (NIST) (2007). Baldrige National Quality Program: 2008 criteria for performance excellence. Retrieved December 8, 2007, from http://baldrige.nist.gov/Business_Criteria.htm

National Institute of Standards and Technology (NIST) (2004). NIST news release: two manufacturers, business school, hospital to receive presidential award for quality and performance excellence. Retrieved November 28, 2007, from http://www.nist.gov/public_affairs/releases/2004baldrigewinners.htm

National Institute of Standards and Technology (NIST) (2007). Malcolm Baldrige National Quality Award 2005 award recipient, manufacturing: Sunny Fresh Foods, Inc.. Retrieved November 26,2007, from http://www.nist.gov/public_affairs/baldrige_2005/ sunnyfresh.htm

National Institute of Standards and Technology (NIST) (2007). Malcolm Baldrige National Quality Award application data 1988-2007. Retrieved March 28, 2008, from http://www.nist.gov/public_affairs/factsheet/nqa_appdata.htm

National Institute of Standards and Technology (NIST) (2004). NIST tech beat. Retrieved December 8, 2007, from http://www.nist.gov/public_affairs/techbeat/tb2004_0423.htm\#q uicklinks

SEIZ, K. (2005). Baking management - part I: The Bama Companies recognized for excellence. Retrieved April 20, 2008, from http://baking-management.com/successful_plants/ bm_imp_9800/

The Bama Companies, Inc. (January, 2006). The Bama Companies, Inc. wins McDonald's $₫$ USA highest quality honor. Retrieved November 26,2007, from http://www.bama.com/default.aspx? page $=20013 \&$ pnt $=0 \& c=$ Hide
The Bama Companies, Inc. (n.d.). History: It started at a soda fountain in Texas. Retrieved November 26, 2007, from http://www.bama.com/default.aspx?page=2 10\&pnt=200

The Bama Companies, Inc. (n.d.). Application summary. Retrieved November 28, 2007, from http://www.quality.nist.gov/ PDF_files/Bama_Application_Summary.pdf

US Consumer Products Safety Commission (2008). April 2008 recalls and product safety news. Retrieved April 20, 2008, from http://www.cpsc.gov/cpscpub/prerel/prerelapr08.html 